\title{
Health care networks: the role of the family health team in child hearing loss
}

\author{
Redes de atenção à saúde: o papel da equipe de saúde \\ da família na perda auditiva infantil
}

Jullyane Florencio Pachêco da Silva(1)

Cleide Fernandes Teixeira(1)

Maria Luiza Lopes Timóteo de Lima ${ }^{(1)}$

Cynthia Maria Barboza do Nascimento(1)

Fabiana de Oliveira Silva Sousa(2)

Silvana Maria Sobral Griz(1)

(1) Universidade Federal de Pernambuco UFPE - Recife (PE), Brasil.

(2) Centro de Pesquisas Aggeu Magalhães/ Fundação Oswaldo Cruz - CPqAM/

Fiocruz - Recife (PE), Brasil.

Source of Financial Support: Coordenação de Aperfeiçoamento de Pessoal de Nível Superior - CAPES

Research conducted at the Programa de Pós-Graduação em Saúde da Comunicação Humana, Universidade Federal de Pernambuco - UFPE - Recife (PE), Brasil.

Conflict of interest: non-existent

Received on: March 21, 2017 Accepted on: July 12, 2017

\section{Mailing address:}

Jullyane Florencio Pachêco da Silva

Av. Prof. Moraes Rego, 1235 -

Cidade Universitária

Recife, Pernambuco, Brasil

CEP: 50670-901

E-mail: jullyanepacheco@gmail.com

\section{ABSTRACT}

Purpose: to understand the network performance of family health staff on child hearing loss.

Methods: a qualitative case-study research. Data collection consisted in three focus groups of family health staff from district IV in the city of Recife. Data were analyzed by meaning condensation.

Results: most professionals perform their functions individually, which might weaken the comprehensive health care. Additionally, the lack of interaction with other complexity levels to meet the various actions and the absence of counter-reference required by the staff prevents the child's ongoing care.

Conclusion: the teams' organization and their relationships with other health care services are surrounded by weaknesses that make assistance ineffective regarding hearing health.

Keywords: Primary Health Care; Family Health Strategy; Child Care; Hearing Loss

\section{RESUMO}

Objetivo: compreender a atuação em rede da equipe de saúde da família diante da perda auditiva infantil.

Métodos: trata-se de uma pesquisa qualitativa a partir do estudo de caso. A coleta de dados consistiu na realização de três grupos focais com as equipes de saúde da família do distrito sanitário IV, no município de Recife. Os dados foram analisados pela condensação de significados.

Resultados: a maioria dos profissionais desempenham suas funções de modo individualizado, o que pode fragilizar a assistência integral à saúde. Associados a isso, a falta de articulação com os demais níveis de complexidade para atender as diversas ações requeridas pela equipe impossibilita o cuidado contínuo da criança.

Conclusão: a organização das equipes e suas relações com outros serviços assistenciais são envoltas por fragilidades que tornam a assistência pouco efetiva no que diz respeito à saúde auditiva.

Descritores: Atenção Primária à Saúde; Estratégia de Saúde da Família; Cuidado da Criança; Perda Auditiva 


\section{INTRODUCTION}

The Primary Health Care (PHC) is characterized by performing actions "at the individual and collective scopes, which includes the promotion and protection of health, disease prevention, diagnosis, treatment, rehabilitation, harm reduction and maintaining health"1. These actions are consolidated by the staff who work in the Family Health Strategy (FHS).

Regarding to child care the family health team have by function to promote care for pregnant women and newborns, monitor growth and child development milestones and be attentive to prevalent diseases in children².

Thus, the entire personnel need to identify and address the different changes of growth, referring children to other levels of care for diagnosis and intervention ${ }^{2}$, assisting in the identification of hearing loss as early as possible.

Hearing loss is configured as one of the main disorders that may interfere with the development of language and speech, which would entail limitations on effective communication and social interaction of the child ${ }^{3}$. In Brazil, it is estimated that approximately three to five per 1,000 newborns have hearing loss, increasing to two to four of every 100 births when from Intensive Care Unit'.

The sensitive global feedback of the professional that integrate family health groups is a facilitating factor for children and families comprehensive care, causing a greater impact on the determinants and conditions of the health-disease process ${ }^{5}$.

Another important factor is the assistance of Family Health Support Centers (FHSC), which expands the number of professionals and provides a greater range and efficiency of PHC. The FHSC staff must be composed by different professionals, working jointly with the Family Health team by the matrix-based strategies support, sharing practices in health ${ }^{6}$.

At the organization of integrated health networks, $\mathrm{PHC}$ is defined as ordering and coordinator of care, from no more than the guideline hierarchy of services, but the communication center position these networks ${ }^{7}$.

Evidently, the integrated action between FHSC and Family Health staff should be supported by the specialized and high complexity care, so that the FHSC is a potentiating network of health care, as recommended by the National Primary Care Policy ${ }^{6}$.

Building a network of care is one of the key strategies within the working logic of FHSC staff, so the creation of internal and external spaces of discussion is very important to strengthen actions to support Health, expanding as well, the resolution of $\mathrm{PHC}$ and reducing unnecessary referrals to other levels of assistance ${ }^{8}$.

Given that the team needs integration in the performance of their duties; knowledge to identify the various changes of growth; a network of care that meets their demands, this study aimed to understand the role of the Family Health team before the children's hearing loss in health care networks.

\section{METHODS}

This is a qualitative study from the case study, which was approved by the Ethics Committee of the Federal University of Pernambuco / Health Sciences Center UFPE in the report 532.851/2014.

The survey was conducted in three Family Health Units (FHU) of the health district IV in the city of Recife. The units were selected by lot, to contemplate each micro-region of the district concerned.

From a FHU random selection, it was chosen three family health teams, one per unit, with the inclusion criteria, complete teams, i.e. those containing family physician, nurse, nursing technicians and Community Health Agent (CHA), and availability of time to participate. In addition, the student interns who were in units and wanted to join the groups were accepted.

Data collection consisted of focus groups. This technique promotes a broader questioning on a particular theme or focus from the group interaction, generating multiple influences participants ${ }^{9}$. The groups ranged from eight to ten, containing at least one representative from each professional category, lasting from 93 to 108 minutes.

Each team was questioned as for the conduct adopted before three cases previously prepared in order to obtain information in accordance with the research objective. The cases were about a child under one year of age who did not react to sounds; the mother's report as to the poor vocabulary and slurred speech of her three-year-old daughter; the poor school performance, exchanges between phonemes and earache complaint of a five-year old child.

The groups were conducted by two researchers: one mediator, who has extensive experience in the used methodology, with function begin, motivate, generate discussion among participants; and an observing and recording operator, responsible for analyzing the group process conduction and handling the recording equipment. 
Meetings with each team took place at an agreed time and date with the collaborators, previous visits were held to FHU to stimulate their attendance and establish a relationship of trust between the participants and the researchers, previous visits were held to FHU to stimulate their attendance and establish a relationship of trust between the participants and the researchers.

Before beginning the focus groups, the mediator created an atmosphere of comfort, arranging the participants in a circle. This arrangement allows good eye contact, consequently, better interaction of the participants ${ }^{10}$ as well as facilitating the record of the meetings, which were audio recorded on a mp4 player. Then, the objective was clear, the Informed Consent form was signed, and clinical cases were presented, leaving participants free to comment.
The speeches were transcribed and qualified based on the interviews analysis model of condensation meanings type ${ }^{11}$, since it suits the purposes of the study and allows compile speeches without losing the essence of the content. After careful reading, the meaning units were determined and defined the central subject issues to be described in the cutouts of the speeches of the teams.

To guarantee the anonymity of the subjects, acronyms were adopted relating to the initial of each profession, followed by the letter indicating the micro area of the team and the number of sequential order, according to the speech of each professional. The follow-up adopted in the identification of each micro area is not related to the order made by the health district IV (Figure 1).

\begin{tabular}{|c|c|c|c|}
\hline PROFESSIONALS & MICRO AREA A & MICRO AREA B & MICRO AREA C \\
\hline Doctor & Doc A & Doc B & Doc C \\
\hline Nurse & Nrs A & Nrs B & Nrs C \\
\hline Nursing technician & Tec A & Tec B & Tec C \\
\hline \multirow{4}{*}{ Community Health Agent } & Cha A1 & Cha B1 & Cha C1 \\
\cline { 2 - 4 } & Cha A2 & Cha B2 & Cha C2 \\
\cline { 2 - 4 } & Cha A3 & Cha B3 & Cha C3 \\
\cline { 2 - 4 } & Cha A4 & Cha B4 & Cha C4 \\
\cline { 2 - 4 } & & Cha B5 & Cha C5 \\
\hline \multirow{2}{*}{ Intern / Students } & Std A (Medicine) & Std B (Nursing) & Std C2 (Nursing) \\
\cline { 2 - 4 } & & & 10 \\
\hline TOTAL & 8 & 9 & 10 \\
\hline
\end{tabular}

Figure 1. Distribution professional and aliases of surveyed participants for micro area $(N=27)$

\section{RESULTS}

The performance of the Family Health teams in face of the child hearing loss in health care networks was analyzed in the categories: 1. Team's network performance; 2. Unfavorable aspects for performance of Family Health team's actions. Within these major categories, other subcategories were explored (Figure 2).

\begin{tabular}{|c|c|}
\hline Key Categories & Subcategories \\
\hline Team's Network Performance & $\begin{array}{c}\text { The staff in the service } \\
\text { Relationship FHS versus FHSC }\end{array}$ \\
$\begin{array}{c}\text { Unfavorable aspects for the performance of Family Health team's } \\
\text { actions }\end{array}$ & $\begin{array}{c}\text { Relationship FHS versus other levels of complexity } \\
\text { insufficient continuing education }\end{array}$ \\
\hline
\end{tabular}

Figure 2. Distribution of categories and subcategories of analysis 


\section{Team's Network Performance}

In the description of the results of this category, the following subcategories were explored: the team in attendance; FHS ratio versus FHSC; FHS relationship versus other levels of complexity.

When asked of the approach adopted in each case presented, it can be observed how the professionals perform in team. It was observed that, on most of the family health teams the professionals perform their duties individually.

When it identifies a child with possible hearing loss during home visits the $\mathrm{CHA}$ of the micro area directs the case to the unit's doctor, while the doctor (Doc C) or nurse (Nrs A), when they identify in their routine visits, request FHSC support or refer to another level of complexity.

I tell the subject to come here to the unit to schedule an appointment and the doctor identify what's going on (Cha A3).

[...] When I identify, I automatically forward to the FHSC speech-language therapist for her to evaluate (Nrs A).

When I identify, I forward to the ENT(Doc C).

Only the team micro area B shown to have greater integration and joint and inter-acting. It was reported that medical and nursing consultations can take place in a shared way, that cases are discussed in staff and everyone involved are heard. From this it is that the directions of actions are decided.

[...] from the moment we identify the case or suspected of such case, we would direct to staff (Cha B2).

[...] or even talk directly to the FHSC speech-language therapist for us to take any questions and schedule a shared visit shared with her, because she would be able to evaluate better than us (Cha B1).

Initially we would do a shared appointment. Surely l'd knock the doctor's door saying what was identified (Nrs B).

We would discuss it in team, surely would request support from FHSC to define the best approach, confirming that it would be a hearing problem, right? After talking to the family if the child has other socializing spaces. Look for a daycare, a school, in short, to identify which would be the best place (Doc B).

As for the relationship with the FHSC, all teams have referred broadly the easy access and good relationship. With regard to hearing and speech issues, we realized a greater proximity of the teams, as there is a speechlanguage therapist at the FHSC.

It was clear to all teams, linking and recognition of the importance of this integration, although it is evident that this perspective is still being worked on to greater and faster problem solving in certain cases.

About engaging FHSC, we have their phone number. I have been talking to them a lot, looking to do this integration. [...] once a month they are here with us. Many times we connect directly to the Speech-language therapist. It is an easy access (Doc B).

The insertion of FHSC was excellent. Greatly increased the resolution to these issues (Doc $A$ ).

Before we referred to the experts and thus taking a long time [...] So, having the FHSC here, we can send the child right away. As they are here all week, nurse does the childcare, assists, evaluates and refers. The doctor being here, promptly helps. It is more resolute $[\ldots]$ (Tec A).

The team of micro area $\mathrm{C}$ which was not included with this professional in FHSC reported that, if needed, would request a speech-language therapist support of another core, but it would be difficult to obtain.

I know it's too difficult to get, but, well, [...] I would ask if the neighbor FHSC could help me in this regard. Because thus the FHSC also has this role to organize and try solve together with the family health (Nrs C).

When the teams were asked about the relationship with other levels of complexity, it was observed that there are referrals to specific referral services and that some units can count on the help of the National Regulatory System (NRS) for scheduling appointments. But, depending on the specialty, such access to appointments is still time consuming. Often patients are advised to seek the emergency care. 
We have access to the National Regulatory System to schedule appointments. We prepare the referral and the unit has a regulator that is scheduling our consultations and already schedules and the $\mathrm{CHA}$ informs the family. When the system is booked, the NRS itself tries to find an expert to assist the situation (Doc C).

Scheduling an appointment with an ENT always takes time. (Cha C4).

We often direct to emergency ENT, because it really takes a lot (Nrs C).

The teams also reported deadlocks in performing the Newborn Hearing Screening (NHS), as many children still leave the maternity without performing the screening.

Access is not easy. Most are for those born in the Institute of Integral Medicine Professor Fernando Figueira (IMIP) and already have scheduled newborn bloodspot screening, otoacoustic emissions and red reflex tests. Now when born elsewhere it is more complicated (Tec A).

Access to the Clinical Hospital is being impossible. Previously we had the option of taking the medical referral and schedule, now cannot do it at all. The referral has to come from a professional of the hospital (Cha B2).

In contrast, only the nurse team of micro area $\mathrm{C}$ claimed to have had the experience of performing a referral and successfully schedule the test by the Regulation Center. The experience was new and no team member had knowledge of this possibility, being seen as a surprise.

[...] I was astonished to have got now, because I myself requested by NRS and my request was accepted. And who told me that we could do this scheduling trough the Regulation center of the OAE test was a user. No one from management came to tell us that it was here to use (NrsC).

Another issue reported by $\mathrm{CHA}$ micro area $\mathrm{C}$ was the possible difficulty in getting a hearing aid if the child needs.

You see that many needs the hearing aid, but network access to the device [...] is very hard. IMIP provides, but for you to get the device from IMIP there is has a whole lot bureaucracy, delay (Cha C1).

\section{Unfavorable aspects for the performance of Family Health team's actions}

In this category, we analyzed the lack of counterreferral and insufficient professional health education focused on the hearing.

All teams reported the absence of counter-referral by other professionals, making it difficult to monitor the child in the unit. The only feedback that the team gets from the specialties is from the patient himself, who, most often, do not you inform with detail and precision what procedures has been done and defined in the specialized care.

There is no counter-referral. Never existed from any professional, nor form the speech-language therapist, nor from the ENT (Nrs C).

We do not have that formal counter-referral, which is something that complain for over 10 years, but we end up knowing something because the family comes and tells (Doc A).

But sometimes do not even know what to say what was defined (NrsC).

[...] at least if it were counter-referred to us, we would be able to monitor that child, know what treatment is being employed, to see what we can help here (Doc B).

The permanent health education also appears in teams as a necessary action for professionals to recognize any changes and know to whom and where to refer, supporting the family and monitoring the health of children in order to promote, prevent and rehabilitate the hearing health effectively.

I never had and never received any continuing education for it (Doc b).

[...] further training in hearing care for family health professionals to detect this problem would be nice. We're always attentive but lack a little technique to us, you know? (Doc A).

The professionals should have constant training. Because, well, [...] you will not remember, nor will always be the same for life (Std B). 
Only one student (Std B) cited training in Integrated Management of Childhood Illness (IMCl) as a way to guide their professional practice. The remaining team members said they had done this course, but for years. Moreover, regarding to health and hearing health, training is weak.

[...] today we already have additional training, which is the $\mathrm{IMCl}$, directed to child care, about signs and the child's symptoms. So, you know to guide your treatment, diagnosis [...] (Std B).

I have $\mathrm{IMCl}$, but I did 10 years ago. So, it is something that if you ask me today, I will remember very few things (Cha B3).

In relation to this training, I also I have. But more so, in relation to discharge, right? Does not say anything about audio, speech, does it? audio assessment? (Nrs B).

\section{DISCUSSION}

It was observed that, on most of the family health teams the professionals perform their duties individually. Only one team showed their integration and inter-acting mode, reaffirming the importance of this integration to build and strengthen a line of care for users.

A study in Minas Gerais, with teams of professionals of family health, support teams and managers of municipalities, totaling 48 subjects, also shows that often the integrating health practices are not contemplated. Each professional performs its function isolated, poorly articulated and not very interactive ${ }^{12}$, with repercussions on the quality of the provided health care.

Fragmentation depreciate the subjects assistance ${ }^{13}$. It is necessary to approach the team members so that the actions are carried out from the point of view of integration ${ }^{14}$. The integration team search the horizontality of the various professions and enables autonomy and creativity of everyone involved. Actions must be built collectively by promoting sharing of the diverse knowledge and practices ${ }^{15}$.

The identification of children with possible hearing loss, as shown in the narrative of the teams can be carried out during home visits of the Community Health Agent or in medical and nursing consultations. The attention of the staff to the child should take place in any care opportunities that arise, either during the sessions at the clinic, at home or in social areas such as daycare and schools ${ }^{16}$.

The Community Health Agent has an important role in the work process, for it is through the constant contact and its proximity to the community that there will be data collection of health problems and hence the transfer to the team seeking solution ${ }^{17}$.

Only one team has reported that in their care practice to doctor visits and nursing care jointly when necessary. This demonstrates that the professionals realize the exercise of completeness in the developed activities and affirm the importance of joint work in child and family care ${ }^{12}$.

Relative to the support offered by FHSC professionals, all teams have reported good integration. The FHSC, in fact, was created in a matrix-based strategies perspective, helping family health teams in the practice of teamwork and increasing the number of professionals, resulting in a $\mathrm{PHC}$ greater range ${ }^{6}$.

It was observed that family health teams that had speech-language therapists in FHSC had greater support issues concerning hearing and speech, unlike the one that did not have an allocated professional and seek support to the adjacent FHSC.

A study in the city of Sobral found that after the insertion of speech-language therapy in the FHS there was a significant increase in the number of referrals to the test of OAE and performed tests. The presence of the speech therapist was essential in monitoring and tracking of early diagnosis of hearing loss, providing improved quality of life for children in the municipality ${ }^{4}$.

The process of labor between family health teams and FHSC, which is based on the matrix-based strategies, expands the possibilities of the construction of singular therapeutic project without creating endless referral paths, comprised by the network. Through matrix-based strategies, the aim is to "re-ordering of health work, according to the guideline of the therapeutic relationship between teams (ESF and FHSC) and users and interdisciplinary practices and knowledge" 18 .

In this arrangement, the family health teams are supported by each professional core that makes up the FHSC to share the longitudinal care of users and families within the municipal health network and / or other local services, such as psychosocial care center (CAPS), Occupational Health Reference Center (CEREST), rehabilitation centers, social and community networks, among others ${ }^{8}$. Importantly, the FHSC should take as a structuring principle of its work complete care 
users and using an expanded concept of the clinic in their daily thinking and promoting health ${ }^{6}$.

In this integrated operation, the FHSC should seek to overcome the fragmented health rationale for the construction of attention and care networks, co-responsible way with family health teams and other equipment / services (health, education, sports, culture, etc.) present in territory ${ }^{19}$.

When asked about the relationship of the FHS with other services, it was reported that the needs of the other levels of complexity, the teams have an appointment scheduling system. The National Regulatory System (NRS) was created in order to manage all regulatory complex, ranging from the core network to the hospital, aimed at humanization of services, to better control the flow and optimize the use of resources. The regulator is responsible for service requests, processing and scheduling appointments ${ }^{20}$.

But still, depending on the specialty, the appointments are still limited. The specialized appointments in otorhinolaryngology is mentioned as one of the hardest to schedule. In addition, depending on the case, often patients are instructed to seek emergency service due to the delay.

The teams reported that access to the performance of OAE is still elementary, restricted to children born in a given hospital, mentioning by health professionals that it is virtually impossible to schedule the screening. This restricted access to other specialties further delay the diagnosis of hearing loss and, consequently, the adoption of intervention measures ${ }^{21}$. In 2014, the Ministry of Health reported that the OAE test coverage was low, about $33 \%$, and estimated that in 2017 the hospitals were equipped with established care flows and coverage of $100 \%{ }^{22}$. But this reality is still distant.

It is emphasized that the assistance services should not work in isolation, and they are co-responsible for the access, comprehensive care and continuity of care to the health of people ${ }^{23}$. A comprehensive care comprises the continuity of care, beyond the reference and counter-referral system ${ }^{24}$.

The professional only become aware of the procedures adopted by the patient himself, who, most often, do not provide detailed and precise information on what has been done and defined. The teams reported that, by referring children to other levels of complexity, do not receive a formal counter-referral from the other specialties, which is also reported in another study ${ }^{25}$.

Continuing education also appears in the debate. The team describes as a necessary action for action to promote, prevent and rehabilitate effectively the hearing changes ${ }^{26}$. Only one student commented on training in $I \mathrm{MCl}$, in order to base her procedures.

Regarding health and hearing care, the approach is geared to ear problems due to infections, not considering the changing aspects of behavior, development of speech and language, for example, which would facilitate the identification of changes in growth and development by the entire team. One of the aspects covered in the $\mathrm{IMCl}$ is "how to assess and classify ear problems." However, as well questioned by the nurse, this activity does not include the entire universe regarding the complexity of coping with hearing loss ${ }^{26}$.

The limitation of this study is to have a non-probabilistic sample, which refers to three FHU in a health district, making inferences restricted to the team context. In order to confirm the findings of this study, further research needs to be conducted with a larger population and in other regions.

\section{CONCLUSION}

The organization of teams and their relationships with other care services are surrounded by weaknesses that make ineffective assistance with regard to hearing health. Most professionals of family health teams perform their duties individually, which can depreciate the comprehensive health care.

In addition, it was observed that some teams access the NRS to facilitate the articulation of PHC with other levels of care. But still, depending on the specialty, such access to scheduling appointments is still restricted. As for the counter-referrals, it was pointed out that this process does not exist, which prevents a better continuity of child care.

All teams reported having a good relationship with the FHSC. With regard to hearing and speech issues, we realized a greater proximity of the teams due to the presence of the speech therapist. This reiterates the importance of integrating these professionals in $\mathrm{PHC}$ to provide technical support for not only language and hearing issues, but also voice, dysphagia and orofacial motor skills. This FHSC-ESF integration is still being crafted to provide greater and faster problem solving and case sharing.

It highlights the need for better understanding of the professionals regarding the integration of its practices as a way to provide quality care; continuing education actions in health for all professionals involved; and effective care network to ensure a comprehensive 
service offering and meet the various actions required by the team.

\section{REFERENCES}

1. Brasil. Ministério da Saúde. Secretaria de Atenção à Saúde. Departamento de Atenção Básica. Política Nacional de Atenção Básica. Brasília: Ministério da Saúde; 2012.

2. Brasil. Ministério da Saúde. Secretaria de Atenção à Saúde. Departamento de Ações Programáticas Estratégicas. Agenda de Compromissos para a Saúde Integral da Criança e Redução da Mortalidade Infantil. 2.ed. Brasília: Ministério da Saúde; 2005.

3. Agrawal Y, Platz EA, Niparko JK. Prevalence of hearing loss and differences by demographic characteristics among US adults. Arch Intern Med. 2008;168(14):1522-30.

4. Maia RM, Silva MAM, Tavares PMB. Newborn hearing health: speech therapy acting on Family Health Strategy. Rev. CEFAC. 2012;14(2):206-14.

5. Viegas SMF, Penna CMM. A construção da integralidade no trabalho cotidiano da equipe saúde da família. Esc Anna Nery. 2013;17(1):133-41.

6. Brasil. Ministério da Saúde. Portaria o 2.488, de 21 de outubro de 2011. Aprova a Política Nacional de Atenção Básica, estabelecendo a revisão de diretrizes e normas para a organização da Atenção Básica, para a Estratégia Saúde da Família (ESF) e o Programa de Agentes Comunitários de Saúde (PACS). [cited 2014 Out 17]. Available from: http:// bvsms.saude.gov.br/bvs/saudelegis/gm/2011/ prt2488_21_10_2011.html

7. Cecilio LCO, Andreazza R, Carapinheiro G, Araújo EC, Oliveira LA, Andrade MGG et al. A Atenção Básica à Saúde e a construção das redes temáticas de saúde: qual pode ser o seu papel? Ciênc. saúde coletiva. 2012;17(11):2893-902.

8. Andrade LMB, Quandt FL, Campos DA, Delziovo CR, Coelho EBS, Pires ROM. Análise da implantação dos Núcleos de Apoio à Saúde da Família no interior de Santa Catarina. Sau \& Transf Soc. 2012;3(1):18-31.

9. Backes DS, Colomé JS, Erdmann RH, Lunardi VL. Grupo focal como técnica de coleta e análise de dados em pesquisas qualitativas. Mundo Saúde. 2011;35(4):438-42.

10. Mazza VA, Melo NSFO, Chieza AM. O grupo focal como técnica de coleta de dados na pesquisa qualitativa: relato de experiência. Cogitare Enferm. 2009;14(1):183-8.

11. Kvale S. Interviews: an introduction to qualitative research interviewing. London: Sage Publications; 1996.

12. Viegas SMF, Penna CMM. Práticas integrais na estratégia saúde da família no Brasil: o quotidiano do trabalho em equipa. Rev Enf Ref. 2013;10(3):99-108.

13. Schwartz TD, Ferreira JTB, Maciel ELN, Lima RCD. Estratégia Saúde da Família: avaliando o acesso ao SUS a partir da percepção dos usuários da Unidade de Saúde de Resistência, na região de São Pedro, no município de Vitória. Ciênc Saúde Coletiva. 2010;15(4):2145-54.

14. Viegas SMF, Penna CMM. A construção da integralidade no trabalho cotidiano da equipe saúde da família. Esc Anna Nery. 2013;17(1):133-41.

15. Cardoso AS, Nascimento MC. Comunicação no Programa Saúde da Família: o agente de saúde como elo integrador entre a equipe e a comunidade. Ciênc Saúde Coletiva. 2010;15(1):1509-20.

16. Cursino EG, Fujimori E. Integralidade como uma dimensão das práticas de atenção à saúde da criança: uma revisão bibliográfica. Rev Enferm UERJ. 2012;20(1):676-80.

17. Santana JCB, Vasconcelos AL, Martins CV, Barros JV, Soares JM, Dutra BS. Agente Comunitário de Saúde: percepções na Estratégia Saúde da Família. Cogitare Enferm. 2009;14(4):645-52.

18. Bezerra RSS, Carvalho MFS, Silva TPB, Silva FO, Nascimento CMB, Mendonça SS et al. Arranjo matricial e o desafio da interdisciplinaridade na atenção básica: a experiência do NASF em Camaragibe/PE. Divulg Saúde Debate. 2010;(46):51-9.

19. Brasil. Ministério da Saúde. Secretaria de Atenção à Saúde. Departamento de Atenção básica. Diretrizes do NASF: núcleo de apoio à saúde da família. Brasília: Ministério da Saúde; 2010.

20. Brasil. Ministério da Saúde. Secretaria de Atenção à Saúde. Departamento de Regulação, Avaliação e Controle de Sistemas. Diretrizes para a implantação de Complexos Reguladores. Brasília: Ministério da Saúde; 2006.

21. Tschoeke SN, Jacob LCB, Marques JM. Estudo do diagnóstico, etiologia e (re)habilitação do deficiente auditivo em um centro da Região Sul. Tuiuti: Ciência e Cultura. 2008;39(1):63-84. 
22. Brasil. Ministério da Saúde. SUS já ofereceu mais de 600 mil aparelhos auditivos nos últimos três anos. Brasília; 2014. [cited 2015 jan 06]. Available from: http://www.blog.saude.gov.br/34696-sus-jaofereceu-mais-de-600-mil-aparelhos-auditivos-nosultimos-tres-anos.html

23. Kuschnir R, Lima LD, Baptista TWF, Machado CV. Configuração da rede regionalizada e hierarquizada de atenção à saúde no âmbito do SUS. In: Gondim R, Grabois V, Mendes Junior WV. Qualificação dos Gestores do SUS. 2ª ed. Rio de Janeiro: Fiocruz; 2011. p.121-51. [cited $2014 \mathrm{dez}$ 23]. Available from: http://www5.ensp.fiocruz.br/biblioteca/dados/ txt_484701327.pdf

24. Machado LM, Colomé JS, Beck CLC. Estratégia de saúde da família e o sistema de referência e de contrarreferência: um desafio a ser enfrentado. $R$ Enferm UFSM. 2011;1(1):31-40.

25. Vieira VCL, Fernandes CA, Demitto MO, Bercini LO, Scochi MJ, Marcon SS. Puericultura na Atenção Primária à Saúde: atuação do enfermeiro. Cogitare Enferm. 2012;17(1):119-25.

26. Melo TM, Alvarenga KF. Capacitação de profissionais da saúde na área de saúde auditiva: revisão sistemática. Rev Soc Bras Fonoaudiol. 2009;14(2):280-6 . 